\title{
STRATEGI PENINGKATAN IMPLEMENTASI PENATAUSAHAAN ASET TETAP PADA PEMERINTAH KOTA BOGOR
}

\author{
Strategy for Improving the Implementations of Fixed Assets Administration in the \\ Government of Bogor City
}

\author{
Radna Rika Aprianti 1, Dwi Rachmina ${ }^{2}$, Trias Andati ${ }^{3}$ \\ 1 Staf Dinas Pertanian Kota Bogor. Jawa Barat. Email: radna_rika@yahoo.com \\ ${ }^{2}$ Staff Pengajar Departemen Agrinisnis, Fakultas Ekonomi dan Manajemen, IPB. Email: \\ dwirachmina@gmail.com \\ ${ }^{3}$ Staff Pengajar Sekolah Bisnis, IPB. Email: trias_andati@yahoo.com
}

\begin{abstract}
The objectives of this research were to analyze the internal and external factor of fixed assets administration at Bogor City government, and to formulate strategies for improving the implementation of fixed assets administrations at Bogor City Government. The method used in this research is analysis of IFE, EFE, SWOT, and QSPM. The results showed in the administration of fixed asset at Bogor City Government, the opportunity for BMD management apparatus for their human resource development be the main strength; BMD management apparatus do not focus on their own duties is main weakness; the central government regulations that support the administration of fixed assets and regular assessments by Audit Board of Indonesia (BPK) is opportunity; and the lack of orderliness of housing developers in the delivery of social facility and public facilities is threat. The priority strategy for the improvement of the implementation of fixed asset management in the Government of Bogor City that is the strategy of increasing the supporting factors of the performance of the BMD management apparatus and the strategy of improving the quality of the BMD management apparatus.
\end{abstract}

Keywords: fixed assets, IE, SWOT, QSPM

\section{ABSTRAK}

Tujuan dari penelitian ini adalah 1) Menganalisis faktor internal dan faktor eksternal penatausahaan aset tetap pada Pemerintah Kota Bogor; 2) Merumuskan strategi peningkatan implementasi penatausahaan aset tetap pada Pemerintah Kota Bogor. Metode yang digunakan pada penelitian ini adalah analisis IFE, EFE, SWOT, dan QSPM. Hasil penelitian menunjukkan bahwa pada penatausahaan aset tetap Pemerintah Kota Bogor kesempatan bagi aparatur untuk pengembangan SDM merupakan kekuatan utama; pengelola BMD masih mengerjakan pekerjaan selain tuposinya merupakan kelemahan utama; aturan pemerintah pusat yang mendukung penatausahaan aset tetap dan dilakukannya evaluasi rutin BPK sebagai peluang; dan tidak tertibnya pengembang dalam penyerahan fasilitas sosial dan fasilitas umum merupakan ancaman. Strategi prioritas untuk peningkatan implementasi penatausahaan aset tetap pada Pemerintah Kota Bogor adalah strategi peningkatan faktor pendukung kinerja aparatur pengelola BMD dan strategi peningkatan kualitas aparatur pengelola BMD.

Kata Kunci: Aset Tetap, IE, SWOT, QSPM

\section{PENDAHULUAN}

Pemerintah daerah harus mampu mengelola sumberdaya yang dimilikinya secara efisien dan efektif, agar sumberdaya yang ada dapat dirasakan manfaatnya oleh masyarakat. Salah satu sumberdaya yang harus dikelola dengan baik adalah barang milik daerah atau yang biasa dikenal dengan aset daerah. Aset daerah merupakan salah satu unsur penting dalam rangka penyelenggaraan pemerintahan dan pelayanan publik yang harus dikelola dengan baik, efisien, efektif, transparan, dan akuntabel.

Penatausahaan merupakan salah satu siklus penting dalam pengelolaan Barang Milik Daerah (BMD). Proses penatausahaan yang baik akan menghasilkan data yang lengkap dan mudah ditelusuri sehingga memudahkan pengelola barang dalam melakukan pekerjaannya. Data yang ada juga digunakan sebagai pedoman untuk 
perencanaan pengadaan dan pemeliharaan barang ditahun-tahun berikutnya. Manfaat lain dari penatausahaan BMD adalah dengan penatausahaan BMD yang tertib akan membawa efek signifikan terhadap kesempurnaan penyajian neraca daerah yang disiapkan untuk keperluan pemeriksaan BPK-RI setiap akhir tahun anggaran berjalan (Kolinug et al. 2015). Penatausahaan aset juga merupakan bagian dari pengamanan aset yaitu pengamanan administratif. Selain berfungsi sebagai alat kontrol sistem, penatausahaan aset harus memenuhi kebutuhan pemerintah di dalam perencanaan, pengadaan, pengembangan, pemeliharaan, maupun penghapusan aset.

Aset tetap merupakan aset yang nilainya paling besar dalam neraca, sehingga informasinya sangat penting dalam laporan keuangan suatu entitas. Karakteristik utama dari aset tetap adalah diperoleh untuk digunakan dalam proses operasional perusahaan, dan tidak dimaksudkan untuk dijual, memiliki masa manfaat yang lama (beberapa tahun), dan secara fisik dapat dilihat wujudnya (Nordiawan et.al, (2008). Lu (2011) mengatakan alasan utama mengapa pemerintahan wajib memperhatikan manajemen aset negaranya adalah karena aktiva tetap memiliki umur yang panjang; aktiva tetap memiliki nilai yang material terhadap sumber daya pemerintahan; karena aset tetap bersifat noncurren; aset tetap rentan terhadap penyusutan yang cepat jika tidak terawat dengan baik selama siklus hidup mereka; dan operasional pemeliharaan aset tetap sepanjang siklus hidupnya menghabiskan sejumlah dana yang jauh lebih besar daripada pengeluaran awal untuk kepemilikan aset tetap tesebut.

Hasil pemeriksaan atas penatausahaan dan pengelolaan aset tetap Pemerintah Kota Bogor tahun 2015 menunjukan hal-hal sebagai berikut: Pemerintah Kota Bogor belum menyelesaikan tindak lanjut rekomendasi hasil pemeriksaan terkait penatausahaan dan pengelolaan aset tahun sebelumnya; Pelaksanaan Inventarisasi Aset tidak sesuai dengan Petunjuk Teknis Pelaksanaan Inventarisasi BMD Pemerintah Kota Bogor; Informasi BMD yang disajikan dalam KIB masih belum lengkap; Terdapat tanah dan peralatan serta mesin yang bernilai Rp.0,00; Aset tetap tanah belum semua tercatat pada buku inventaris dan KIB A; Terdapat tanah yang tidak diketahui keberadaannya; serta Penilaian aset tanah, gedung dan bangunan, serta jalan, irigasi dan jaringan yang disajikan dalamNeraca per 31 Desember 2015 tidak sesuai dengan SAP. Melihat masalah di atas dan pentingnya penatausahaan aset tetap maka perlu dilakukan kajian mengenai "Strategi peningkatan implementasi penatausahaan aset tetap pada Pemerintah Kota Bogor".

Tujuan dari penelitian ini adalah: (1) Menganalisis faktor internal dan faktor eksternal penatausahaan aset tetap pada Pemerintah Kota Bogor; (2) Merumuskan strategi peningkatan implementasi penatausahaan aset tetap pada Pemerintah Kota Bogor.

\section{METODE PENELITIAN}

\section{Metode Penentuan Sampel}

Sampel pada penelitian ini ditentukan menggunakan metode purposive sampling, yaitu pengelola BMD pada Organisasi Perangkat Daerah (OPD) yang mempunyai semua jenis aset tetap yaitu mempunyai KIB A, B, C, D, E, dan F. Organisasi Perangkat Daerah yang memenuhi syarat tersebut adalah Dinas Pendidikan (DisDik) Kota Bogor, Dinas Binamarga dan Sumberdaya Air (DisBimaSDA) Kota Bogor dan Badan Pengelolaan Keuangan dan Aset Daerah (BPKAD) Kota Bogor. Responden pada penelitian ini adalah pengurus barang, penyimpan barang, esselon IV, dan esselon III yang bertanggung jawab atas penatausahaan aset tetap pada OPD. Daftar resposden disajikan dalam Tabel 1. 
Tabel 1. Daftar responden penelitian

\begin{tabular}{lllcccc}
\hline \multirow{2}{*}{ No } & \multirow{2}{*}{ Tujuan } & \multicolumn{2}{c}{ Responden } & \multicolumn{4}{c}{ Jumlah Responden } \\
\cline { 3 - 6 } & & DisDik & DisBimaSDA & BPKAD & Total \\
\hline 1 & $\begin{array}{l}\text { Informasi awal } \\
\text { faktor internal } \\
\text { dan eksternal }\end{array}$ & $\begin{array}{l}\text { Pengurus barang dan } \\
\text { penyimpan barang }\end{array}$ & 2 & 4 & 0 & 6 \\
2 & IFE, EFE & Esselon IV & 1 & & & \\
3 & SWOT & Kabid Aset & & 1 & 1 & 3 \\
4 & QSPM & Esselon III & 1 & 1 & 1 & 3 \\
\hline & & Jumlah & 4 & 6 & 2 & 12 \\
\hline
\end{tabular}

Ket: * konfirmasi faktor internal dan faktor eksternal, serta strategi yang sudah dirumuskan, sama dengan responden QSPM

Tabel 2 menunjukkan bahwa jumlah semua responden yang digunakan dalam penelitian ini adalah sebanyak 12 orang, yang berasal dari DisDik Kota Bogor, DisBimaSDA Kota Bogor, dan BPKAD Kota Bogor. Berikut uraian masingmasing responden:

1. Pengurus barang dan Penyimpan barang sebagai staf yang membantu tugas penatausahaan aset di OPD. Wawancara dilakukan untuk menggali informasi awal tentang faktor internal dan faktor eksternal penatausahaan aset tetap pada Pemerintah Kota Bogor.

2. Esselon IV yang dijadikan responden merupakan esselon IV yang tugasnya berkaitan langsung dari penatausahaan BMD pada DisDik Kota Bogor, DisBimaSDA Kota Bogor, dan BPKAD Kota Bogor. Wawancara dilakukan untuk memberikan bobot dan rating pada setiap faktor internal kunci dan faktor eksternal kunci yang telah dirumuskan.

3. Esselon III yang dijadikan responden merupakan esselon III yang tugasnya berkaitan langsung dari penatausahaan BMD pada DisDik Kota Bogor, DisBimaSDA Kota Bogor, dan BPKAD Kota Bogor. Wawancara dilakukan untuk merumuskan strategi prioritas yaitu memberikan skor daya tarik setiap faktor kunci terhadap alternatif strategi yang telah disusun. \\ Metode Pengumpulan Data}

Jenis data yang digunakan dalam penelitian ini adalah data primer yang diperoleh dari wawancara dengan responden. Wawacara digunakan sebagai teknik pengumpulan data apabila peneliti ingin melakukan studi pendahuluan untuk menemukan permasalahan yang harus diteliti, dan juga apabila peneliti ingin mengetahui hal-hal dari responden yang lebih mendalam dan jumlah respondennya sedikit/kecil (Sugiyono 2010). Dalam kajian ini wawancara dilakukan adalah wawancara terstruktur yaitu pengumpul data telah menyiapkan instrumen penelitian berupa pertanyaan-pertanyaan tertulis yang alternatif jawabannya telah disiapkan. Kuisioner disusun sebagai panduan atau alat bantu saat melakukan wawancara dengan responden. Kuesioner yang disusun berupa kuisioner dengan pertanyaan tertutup yaitu pertanyaan yang mengharapkan jawaban singkat atau mengharapkan responden untuk memilih salah satu alternatif jawaban yang tersedia.

\section{Metode Analisis Data}

Faktor internal dan faktor eksternal pada penatausahaan aset tetap Pemerintah Kota Bogor diidentifikasi berdasarkan wawancara dengan pengurus barang dan penyimpan barang pada DisDik Kota Bogor dan DisBimaSDA Kota Bogor. Hasil wawancara dikonfirmasi ke Kabid Aset BPKAD Kota Bogor untuk meyakinkan bahwa faktor-faktor yang diperoleh sudah sesuai dengan kondisi penatausahaan aset tetap pada Pemerintah Kota Bogor. Selanjutnya dilakukan wawancara terstruktur dengan Esselon IV yang membidangi pengelolaan BMD pada DisBimaSDA Kota Bogor, Disdik Kota Bogor, dan BPKAD Kota Bogor untuk 
mengetahui bobot dan rating setiap faktor sehingga dapat disimpulkan faktor internal utama dan faktor eksternal utama dalam penatausahaan aset tetap pada Pemerintah Kota Bogor dengan melihat skor tertimbang masing-masing faktor.

Skor tertimbang berkisar antara 1.0 sampai 4.0. Pada analisis IFE jika total skor tertimbang dibawah 2.5 mengindikasikan bahwa organiasi mempunyai kelemahan internal, sementara jika total skor tertimbang diatas 2.5 mengindikasikan posisi internal yang kuat. Pada analisis EFE Jika total skor tertimbang tinggi (diatas 2.5) berarti pemerintah daerah merespon dengan baik terhadap kesempatan dan ancaman yang ada. Sebaliknya jika total skor tertimbang rendah mengindikasikan bahwa pemerintah tidak memanfaatkan kesempatan atau tidak menghindari ancaman yang ada. Jumlah faktor tidak mempengaruhi pada kisaran total skor tertimbang karena total bobot selalu jumlahnya 1.0 (David dan David 2016).

\section{Perumusan Strategi}

Perumusan strategi didahului dengan melihat posisi penatausahaan aset tetap di Kota Bogor dengan menggunakan matrik IE, kemudian merumuskan strategi alternatif menggunakan matrik SWOT, dan strategi prioritas menggunakan analisis QSPM. Matrik IE digunakan untuk melihat posisi penatausahaan aset tetap pada Pemerintah Kota Bogor berada di kuadran berapa. David dan David (2016) mengatakan matrik IE secara garis besar dibagi dalam tiga bagian yaitu sel I, II, dan IV sebagai kuadran tumbuh dan berkembang (grow and build/GB), sel III, $\mathrm{V}$, dan VII sebagai kuadran menjaga dan mempertahankan (hold and maintain/HM), serta sel VI, VIII, dan IX sebagai kuadran panen dan divestasi (harvest or divest/HD). Kedudukan atau posisi penatausahaan aset tetap Kota Bogor digunakan dalam merumuskan strategi yang tepat untuk perbaikan penatausahaan aset yang dilakukan pada tahap berikutnya.
Analisis SWOT dilakukan dengan melihat empat faktor penting yaitu $\mathrm{S}$ (strenght) atau kekuatan, W (weakness) atau kelemahan, $\mathrm{O}$ (opportunity) atau peluang dan $\mathrm{T}$ (treath) atau ancaman. Faktor-faktor ini telah ditentukan pada tahap sebelumnya (matrik IFE dan EFE). Langkah-langkah dalam merumuskan strategi dengan matriks SWOT meliputi Membuat daftar kesempatan eksternal kunci, ancaman eksternal kunci, kekuatan internal kunci, dan kelemahan internal kunci yang diambil dari matriks EFE dan IFE yang telah dianalisa sebelumnya; Merumuskan strategi yang cocok untuk kekuatan internal dengan kesempatan eksternal, kelemahan internal dengan kesempatan eksternal, kekuatan internal dengan ancaman eksternal dan kelemahan internal dengan ancaman eksternal. Strategi yang dihasilkan dikonfirmasikan kepada Kabid Aset BPKAD Kota Bogor.

Berdasarkan data alternatif strategi yang sudah dirumuskan dalam analisis SWOT, langkah selanjutnya menentukan strategi prioritas dengan menggunakan metode Quantitative Strategic Planning Matrix (QSPM). Analisis QSPM merupakan analisis kuantitatif yang digunakan untuk memilih strategi yang dapat diimplementasikan berdasarkan tingkat kepentingannya. QSPM menggunakan input dari analisis IFE dan EFE dan mencocokkan dengan hasil analisis SWOT.

\section{HASIL DAN PEMBAHASAN}

\section{Analisis Faktor Internal dan Eksternal Penatausahaan Aset Tetap}

Analisis faktor internal dan analisis faktor eksternal dilakukan untuk mengetahui faktor-faktor yang menjadi kekuatan, kelemahan, peluang, dan ancaman penatausahaan aset tetap pada Pemerintah Kota Bogor. Faktor internal adalah faktor-faktor yang berasal dari dalam Pemerintah Kota Bogor berupa kekuatan maupun kelemahan yang ada pada penatausahaan aset tetap. Faktor eksternal adalah faktor-faktor yang 
berasal dari luar Pemerintah Kota Bogor berupa peluang maupun ancaman terhadap penatausahaan aset tetap.

Daftar faktor internal dan faktor eksternal ditentukan dengan melakukan penggalian informasi kepada staf yang bertanggungjawab atas penatausahaan aset tetap pada DisDik Kota Bogor dan DisBimaSDA Kota Bogor. Hasil analisis disusun dalam bentuk daftar faktor internal dan daftar faktor eksternal kemudian dikonfirmasikan kepada Kabid Aset BPKAD Kota Bogor sebelum disusun menjadi kuesioner IFE dan IFE.
Kuesioner ini dijadikan sebagai alat wawancara kepada responden dalam analisis matrik IFE dan matrik EFE. Dari hasil wawancara ditetapkan sepuluh faktor internal dan delapan faktor eksternal yang mempengaruhi penatausahaan aset tetap di Kota Bogor.

Faktor internal yang menjadi kekuatan dan kelemahan penatausahaan aset tetap di Pemerintah Kota Bogor ditampilkan dalam Tabel 2. Bobot diperoleh melalui wawancara diolah dengan metode paired comparison.

\section{Tabel 2. Matrik IFE}

\begin{tabular}{|c|c|c|c|c|}
\hline \multirow{2}{*}{ No } & Faktor Strategis Internal & Bobot & Rating & Skor \\
\hline & \multicolumn{4}{|l|}{ Kekuatan } \\
\hline 1 & $\begin{array}{l}\text { Pemahaman yang baik aparatur Pengurus Barang dan Penyimpan } \\
\text { Barang tentang proses penatausahaan aset tetap }\end{array}$ & 0.104 & 3.333 & 0.346 \\
\hline 2 & $\begin{array}{l}\text { Kuantitas aparatur Pengurus Barang dan Penyimpan Barang telah } \\
\text { mencukupi }\end{array}$ & 0.087 & 3.000 & 0.261 \\
\hline 3 & Penatausahaan aset tetap telah dilakukan secara komputerisasi & 0.104 & 3.667 & 0.380 \\
\hline 4 & $\begin{array}{l}\text { Adanya kesempatan bagi aparatur Pengengurus Barang dan } \\
\text { Penyimpan Barang untuk pengembangan SDM }\end{array}$ & 0.117 & 3.333 & $\mathbf{0 . 3 8 9}$ \\
\hline \multirow[t]{3}{*}{5} & Adanya Perda yang mengatur pengelolaan BMD & 0.083 & 3.000 & 0.250 \\
\hline & Total & & & 1.626 \\
\hline & Kelemahan & & & \\
\hline 1 & $\begin{array}{l}\text { Dokumen penatausahaan aset tetap di Kota Bogor belum terisi } \\
\text { secara lengkap }\end{array}$ & 0.102 & 1.667 & 0.170 \\
\hline 2 & $\begin{array}{l}\text { Pengurus Barang dan Penyimpan Barang masih mengerjakan } \\
\text { pekerjaan selain tugas pokok dan fungsinya sebagai pengelola BMD }\end{array}$ & 0.106 & 1.667 & $\mathbf{0 . 1 7 6}$ \\
\hline 3 & Penempatan pegawai belum sesuai dengan kompetensinya & 0.100 & 1.667 & 0.167 \\
\hline 4 & Sistem insentif pengelola BMD belum sesuai dengan beban kerja & 0.111 & 1.333 & 0.148 \\
\hline \multirow[t]{3}{*}{5} & Sistem aplikasi BMD belum bisa diimplementasikan & 0.087 & 2.000 & 0.174 \\
\hline & Total & & & 0.835 \\
\hline & TOTAL IFE & 1.000 & & 2.460 \\
\hline
\end{tabular}

Hasil analisis matrik IFE (Tabel 2) menunjukkan bahwa total nilai IFE masih berada di bawah 2.5 hal ini berarti masih terdapat kelemahan-kelemahan penatausahaan aset tetap pada Pemerintah Kota Bogor. Faktor yang dianggap sebagai kelemahan utama adalah Pengurus Barang dan Penyimpan Barang masih mengerjakan pekerjaan diluar tugas pokok dan fungsinya sebagai pengelola BMD. Hal ini menyebabkan beberapa aparatur pengelola BMD tidak fokus melaksanakan tupoksinya. Faktor yang dianggap sebagai kekuatan utama penatausahaan aset tetap pada Pemerintah Kota Bogor adalah adanya kesempatan untuk melakukan pengembangan SDM bagi aparatur Pengurus Barang dan Penyimpan Barang. Hal ini menunjukkan bahwa Pemerintah Kota Bogor mendukung peningkatan kualitas aparatur Pengurus Barang dan Penyimpan Barang. 
Pengembangan SDM yang dilakukan oleh Bagian Aset DPKAD berupa bimbingan teknis, sosialisasi aturan, dan workshop. Untuk pendidikan dan pelatihan diselenggarakan oleh Badan Kepegawaian dan Pengembangan Sumber Daya Aparatur Kota Bogor.

Beberapa hasil penalitian mengatakan hal sebagai berikut pemahaman aparatur mempengaruhi kemampuan aparatur dalam pelaksanaan tugasnya, dan persediaan data aset yang tidak baik menjadi kelemahan utama Kota Makasar dalam penerapan prinsip-prinsip dan mekanisme pengelolaan New Publik Manajemen/NPM, Barata et al (2015); Regulasi berpengaruh secara bersamasama maupun secara parsial terhadap manajemen aset Azhar et al (2015). Kompetensi SMD berpengaruh terhadap manajemen aset pada satuan kerja di lingkungan BKKBN se Indonesia Alrini et al (2014). Selain kompetensi sumberdaya manusia, sistem informasi berpengaruh signifikan terhadap sistem pengendalian intern dalam penatausahaan barang milik daerah di Kabupaten Bogor Antoni (2016). Faktor-faktor diatas ditemukan juga pada penatausahaan aset tetap di Pemerintah Kota Bogor.

Selain faktor internal, terdapat juga faktor eksternal pada penatausahaan aset tetap di Kota Bogor. Faktor eksternal penatausahaan aset tetap meliputi peluang dan ancaman (Tabel 3). Aturan ditingkat pemerintah pusat yang mendukung pelaksanaan penatausahaan aset tetap dan adanya evaluasi rutin dari BPK merupakan faktor peluang utama pada Pemerintah Kota Bogor. Adanya aturanaturan ini menjadikan pemerintah daerah menpunyai pondasi yang kuat untuk membuat atau melaksanakan aturan ditingkat pemerintah daerah. Pemeriksaan rutin BPK dianggap sebagai peluang penatausahaan aset tetap di Kota Bogor karena dengan adanya evaluasi rutin maka Pemerintah Kota Bogor selalu berusaha untuk menyajikan laporan sesuai dengan aturan yang ada, agar meminimalisir temuan atau kesalahan saat di audit.
Pemeriksaan rutin BPK juga dianggap sebagai kesempatan untuk memperbaiki kesalahan-kesalahan dalam pelaksanaan penatausahaan aset tetap. Faktor eksternal yang menjadi ancaman utama penatausahaan aset tetap pada Pemerintah Kota Bogor adalah tidak tertibnya pengembang dalam penyerahan fasilitas social (fasos) dan fasilitas umum (fasum) yang menjadi kewajibannya. Fasos atau fasum yang dibuat oleh pengembang harus diserahkan kepemilikannya kepada pemerintah daerah sesuai dengan kontrak yang telah disepakati oleh pihak pengembang, namun banyak pengembang yang tidak melakukan serah terima dengan Pemerintah Kota Bogor. Hal ini menyebabkan nilai aset tetap yang tercatat lebih rendah dibandingkan nilai yang seharusnya. Selain itu pemeliharaan dan rehabilitasi fasos fasum tersebut tidak dapat dilakukan oleh Pemerintah Kota Bogor.

Faktor eksternal pada Tabel 3 juga didukung oleh hasil penelitian Assey et al, (2014) mengatakan bahwa audit seharusnya dilakukan tidak hanya satu kali dalam setahun, karena hasil penelitiannya menemukan bahwa verifikasi fisik aset yang hanya dilakukan satu kali setahun saat audit pada Instansi Pemerintah Daerah di Tanzania menyebabkan penanganan masalah aset terlambat sehingga meningkatkan resiko kehilangan aset tetap. Sihombing (2016) menyimpulkan indikator Peraturan pemerintah pusat tentang tata kelola aset daerah dan Dana insentif daerah (DID) pusat bagi pemerintah daerah yang berkinerja baik merupakan dua indikator yang dianggap sebagai peluang yang dapat mempengaruhi kinerja aparatur pengelola aset di Kabupaten Tapanuli Tengah. Antoni (2016) salah satu ancaman pada penguatan system pengendalian intern dalam penatausahaan BMD di Kab Bogor adalah pengakuan hak pribadi/kelompok/ perusahaan atas BMD (tanah). Hal ini merupakan salah satu prilaku masyarakat yang menyulitkan penatausahaan aset daerah. 
Tabel 3. Martiks EFE

\begin{tabular}{|c|c|c|c|c|}
\hline \multirow{2}{*}{ No } & Faktor Strategis Eksternal & Bobot & Rating & Skor \\
\hline & Peluang & & & \\
\hline 1 & $\begin{array}{l}\text { Aturan ditingkat pemerintah pusat mendukung dalam } \\
\text { pelaksanaan penatausahaan aset tetap }\end{array}$ & 0.125 & 3.67 & $\mathbf{0 . 4 5 8}$ \\
\hline 2 & $\begin{array}{l}\text { Adanya evaluasi rutin dari BPK terhadap dokumen } \\
\text { penatausahaan BMD memberikan motivasi terhadap aparatur } \\
\text { agar melakukan penatausahaan aset tetap lebih baik }\end{array}$ & 0.125 & 3.67 & 0.458 \\
\hline 3 & $\begin{array}{l}\text { Berkembangannya arus teknologi komunikasi memberikan } \\
\text { peluang untuk melalukan efisiensi dan efektivitas dalam } \\
\text { komunikasi antar instansi }\end{array}$ & 0.092 & 3.67 & 0.338 \\
\hline 4 & $\begin{array}{l}\text { Tersedianya program-program diklat pengelolaan BMD oleh } \\
\text { lembaga pemerintah dan perguruan tinggi dalam upaya } \\
\text { meningkatkan pengetahuan aparatur }\end{array}$ & 0.104 & 3.33 & 0.347 \\
\hline \multirow[t]{3}{*}{5} & $\begin{array}{l}\text { Diberikannya Dana Insentif Daerah (DID) pusat, bagi } \\
\text { pemerintah daerah yang berkinerja baik }\end{array}$ & 0.140 & 3.00 & 0.420 \\
\hline & \multicolumn{3}{|l|}{ r } & 2.022 \\
\hline & Ancaman & & & \\
\hline 1 & $\begin{array}{l}\text { Prilaku masyarakat yang menyulitkan proses penatausahaan } \\
\text { aset daerah (pada fasilitas umum) }\end{array}$ & 0.149 & 2.00 & 0.298 \\
\hline 2 & $\begin{array}{l}\text { Keterbatasan jumlah SDM penilai pemerintah (KPKNL) } \\
\text { sehingga menyulitkan Pemkot dalam menilai aset yang belum } \\
\text { mempunyai nilai }\end{array}$ & 0.140 & 2.33 & 0.326 \\
\hline \multirow[t]{3}{*}{3} & $\begin{array}{l}\text { Tidak tertibnya pengembang dalam penyerahan Fasos Fasum } \\
\text { yang menjadi kewajibannya }\end{array}$ & 0.125 & 3.00 & 0.375 \\
\hline & $\begin{array}{ll} & \text { Total } \\
\end{array}$ & & & 0.999 \\
\hline & TOTAL EFE & 1.000 & & 3.021 \\
\hline
\end{tabular}

\section{Strategi Peningkatan Implementasi Penatausahaan Aset Tetap}

Perumusan strategi peningkatan implementasi penatausahaan aset tetap diawali dengan matrik IE, untuk melihat posisi penatausahaan aset tetap Kota Bogor. Dilanjutkan dengan matriks SWOT untuk merumuskan alternatif strategi, dan tahap terakhir adalah menentukan strategi prioritas menggunakan QSPM.

\section{Matrik IE}

Matriks IFE dan Matriks EFE digabungkan menjadi matrik IE untuk melihat posisi penatausahaan aset tetap pada Pemerintah Kota Bogor. Hasil analisis menunjukkan posisi 52 penatausahaan aset tetap pada Pemerintah Kota Bogor berada pada kuadran II yaitu pada posisi grow and build atau pada posisi tumbuh dan berkembang (Tabel 4). Hal ini sesuai dengan kondisi penatausahaan aset tetap di Kota Bogor pada saat ini. Pemerintah Kota Bogor dalam tahap terus melakukan upaya-upaya perbaikan terhadap penatausahaan yang ada saat ini. Pemerintah dalam hal ini Bagian Aset DPKAD Kota Bogor terus berupaya melengkapi data aset tetap yang masih kurang, menambah jumlah pengurus barang dan penyimpan barang, meningkatkan kemampuan aparatur untuk melakukan penatausahaan aset tetap, dan melakukan penilaian terhadap aset tetap yang masih tidak diketahui nilainya. Penatausahaan aset tetap dalam posisi berkembang maksudnya adalah Pemerintah Kota Bogor terus mengembangkan fokus perbaikan penatausahaan aset tetap pada lingkup yang lebih luas. Perbaiakan penatausahaan aset tetap tidak hanya 
dilakukan pada OPD namun instansi yang lebih kecil seperti UPTD, kelurahan, sekolah juga mulai dibenahi dengan menempatkan Pembantu Pengurus Barang.

Tabel 4 Hasil analisis IE terhadap penatausahaan aset tetap pada Pemerintah Kota Bogor

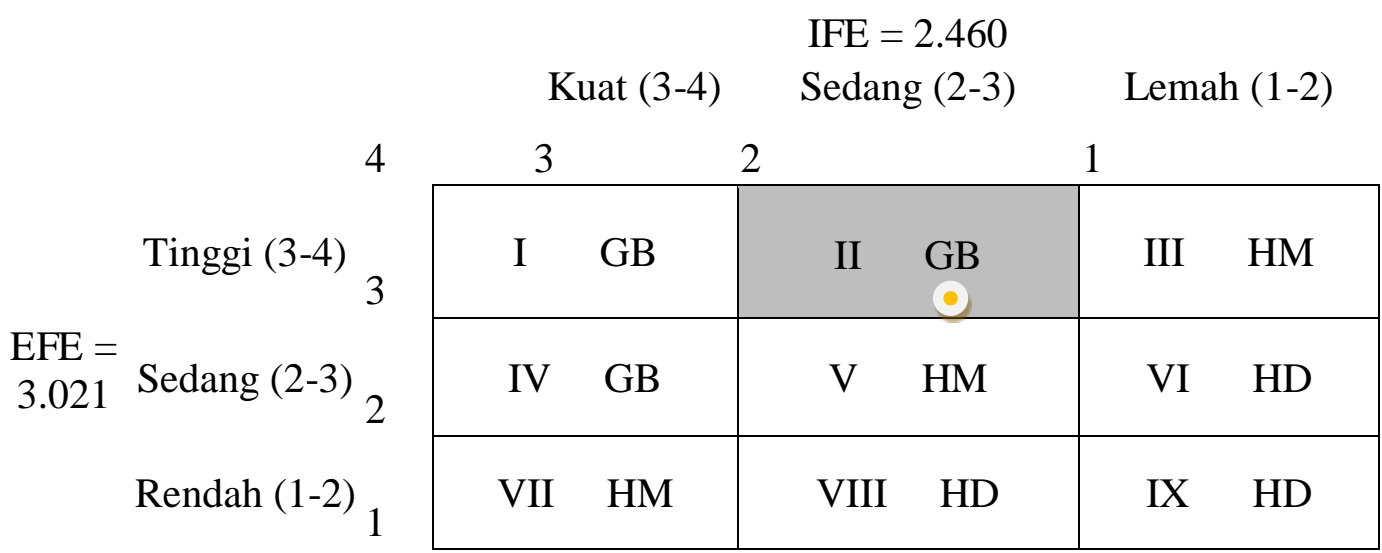

Penatausahaan aset tetap di Kota Bogor yang berada pada kuadran II grow and built harus terus ditingkatkan agar menjadi lebih baik dengan meningkatkan nilai IFE yang masih 2.460 menjadi minimal tiga sehingga mencapai nilai maksimal pada range kuadran II. Untuk itu perlu disusun strategi-strategi yang intensif dan intergratif dalam penatausahaan aset tetap. Strategi yang intensif yaitu strategi yang menunjukkan pelaksanaan penatausahaan aset tetap yang dilakukan secara serius dan terus menerus, strategi ini berhubungan dengan kemampuan aparatur dalam menyelesaikan tugasnya. Faktor yang harus ditingkatkan antara lain kualitas sumberdaya aparatur pengurus barang dan penyimpan barang, dan kualitas data aset tetap. Strategi integratif merupakan strategi yang memadukan berbagai aspek dalam penatausahaan aset tetap, hal ini berhubungan dengan kinerja aparatur pengurus barang dan penyimpan barang. Kinerja aparatur tidak hanya tergantung pada kualitas aparatur tersebut, tetapi juga tergantung dari faktor lingkungan sekitarnya seperti lingkungan kerja, komitmen pimpinan, serta sarana dan prasarana yang menunjang pekerjaan tersebut.

Strategi tersebut sejalan dengan hasil penelitian Sihombing (2016) yang mengatakan kegiatan peningkatan sumber daya manusia merupakan bagian dari ilmu manajemen yang memfokuskan pada pengaturan peranan SDM dalam kegiatan peningkatan kinerja. Pengelolaan SDM harus memperhatikan program peningkatan kinerja secara kesinambungan dan dilakukan secara intensif agar sistem dapat berjalan dengan baik. Beberapa aspek penting seperti sosialisai, bimtek, diklat dan data aset yang terintegrasi mempermudah pengelolaan aset.

\section{Analisis SWOT}

Matrik SWOT merupakan alat pencocokan tahap dua yang bertujuan menghasilkan strategi alternatif yang layak, bukan untuk menentukan strategi terbaik (David dan David 2016). 
Tabel 5 Hasil analisis SWOT terhadap penatausahaan aset tetap di Kota Bogor

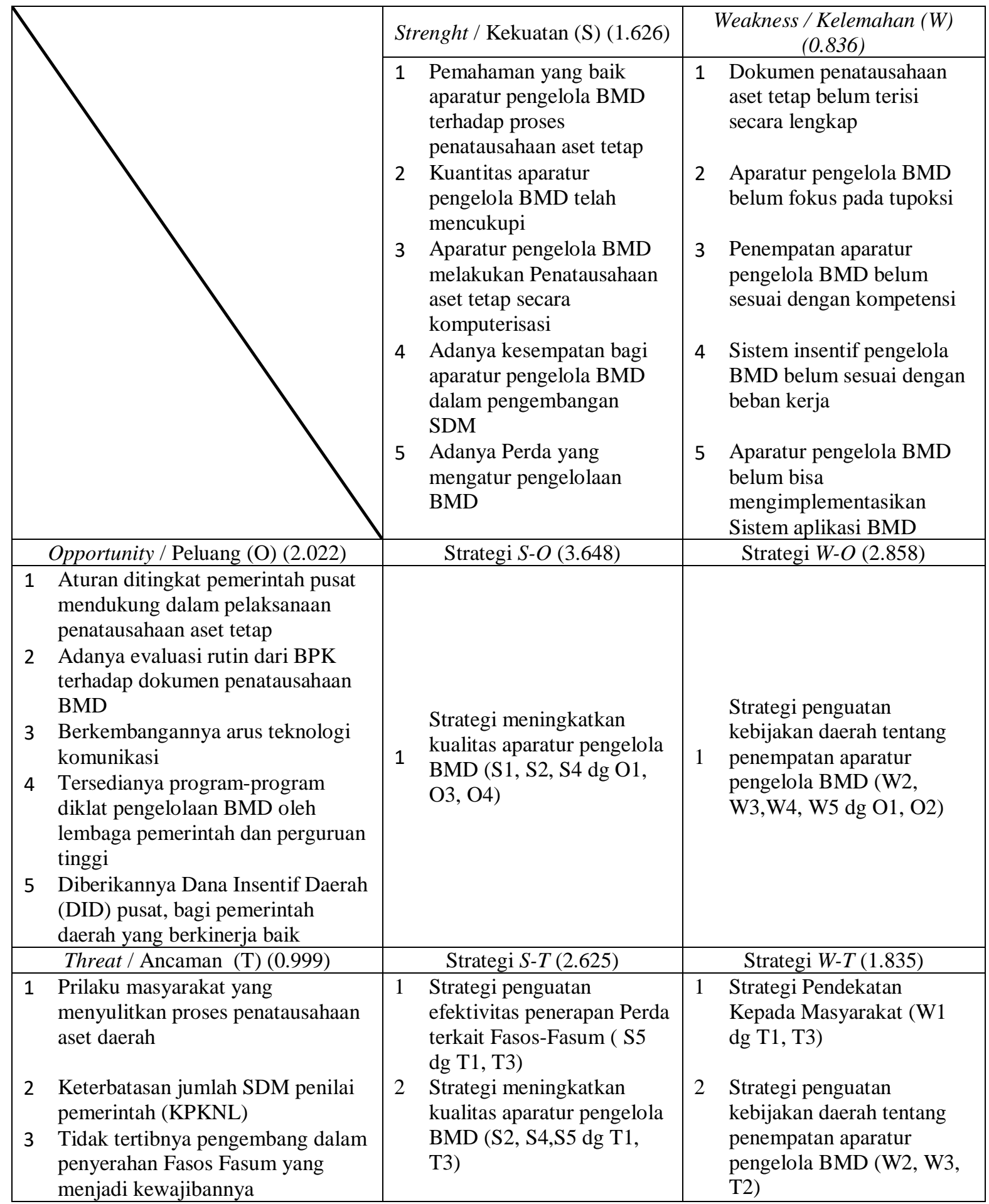

Pada kajian ini strategi alternatif yang disusun tidak hanya memperhatikan kombinasi faktor internal dan faktor eksternal, namun juga memperhatikan posisi penatausahaan aset tetap Kota 54 Bogor yang dihasilkan analisis IE, sehingga strategi yang disusun harus bersifat strategi intensif dan integratif.
Hasil pengolahan data pada Matrik SWOT menghasilkan delapan strategi alternatif. Terdapat dua strategi yang sama pada beberapa kuadran yaitu strategi peningkatan kualitas aparatur (terdapat pada kuadran S-O, kuadran S-T, dan kuadran W-O) dan strategi peguatan kebijakan daerah tentang penempatan 
aparatur pengelola BMD (terdapat pada kuadran W-O dan W-T). Strategi yang sama tersebut dianggap satu strategi walaupun latar belakang munculnya strategi tersebut dari faktor yang berbedabeda. Uraian kombinasi masing-masing faktor internal dan factor eksternal yang membentuk strategi alternatif pada matrik SWOT dapat dilihat pada Tabel 5. Lima strategi yang dihasilkan Matrik SWOT yaitu:

1. Strategi peningkatan kualitas aparatur pengelola BMD

2. Strategi peningkatan faktor pendukung kinerja aparatur pengelola BMD

3. Strategi penguatan kebijakan daerah tentang penempatan aparatur pengelola BMD

4. Strategi penguatan evektifitas penerapan perda tentang Fasos dan Fasum
5. Strategi pendekatan kepada
masyarakat

\section{Analisis QSPM}

Untuk mengetahui strategi prioritas dari lima strategi alternatif hasil analisis SWOT dilakukan analisis QSPM. Analisa ini dilakukan dengan mengalikan bobot setiap faktor dengan skor daya tarik atau attractive scor (AS) terhadap strategi yang dihasilkan pada analisis SWOT. Hasil perhitungan Total Attractive Score (TAS) ditampilkan dalam Tabel 23. Prioritas strategi dilihat dari Sum Total Attractive Score (STAS) pada setiap strategi. Strategi dengan STAS paling tinggi adalah strategi yang dianggap sebagai strategi prioritas.

Tabel 6 Hasil Analisis QSPM Terhadap Penatausahaan Aset Tetap Pemerintah Kota Bogor

\begin{tabular}{|c|c|c|c|c|c|c|c|c|c|c|c|}
\hline \multirow{2}{*}{$\begin{array}{c}\text { Faktor } \\
\text { Strategis }\end{array}$} & \multirow{2}{*}{ Bobot } & \multicolumn{2}{|l|}{$\mathrm{S} 1$} & \multicolumn{2}{|l|}{$\mathrm{S} 2$} & \multicolumn{2}{|l|}{ S3 } & \multicolumn{2}{|l|}{ S4 } & \multicolumn{2}{|l|}{ S5 } \\
\hline & & AS & TAS & AS & TAS & AS & TAS & AS & TAS & AS & TAS \\
\hline \multicolumn{12}{|c|}{ Kekuatan } \\
\hline A & 0.10 & 3.67 & 0.38 & 3.67 & 0.38 & 3.33 & 0.35 & 3.67 & 0.38 & 2.67 & 0.28 \\
\hline B & 0.09 & 3.67 & 0.32 & 3.67 & 0.32 & 3.67 & 0.32 & 3.00 & 0.26 & 2.33 & 0.20 \\
\hline $\mathrm{C}$ & 0.10 & 3.33 & 0.35 & 3.33 & 0.35 & 3.67 & 0.38 & 2.67 & 0.28 & 2.67 & 0.28 \\
\hline $\mathrm{D}$ & 0.12 & 3.67 & 0.43 & 3.67 & 0.43 & 4.00 & 0.47 & 2.67 & 0.31 & 2.67 & 0.31 \\
\hline $\mathrm{E}$ & 0.08 & 2.67 & 0.22 & 3.33 & 0.28 & 3.00 & 0.25 & 3.00 & 0.25 & 2.33 & 0.19 \\
\hline \multicolumn{12}{|c|}{ Kelemahan } \\
\hline $\mathrm{G}$ & 0.10 & 3.00 & 0.31 & 3.33 & 0.34 & 2.33 & 0.24 & 2.33 & 0.24 & 2.00 & 0.20 \\
\hline $\mathrm{H}$ & 0.11 & 3.67 & 0.39 & 3.33 & 0.35 & 3.33 & 0.35 & 2.67 & 0.28 & 2.33 & 0.25 \\
\hline I & 0.10 & 4.00 & 0.40 & 3.67 & 0.37 & 3.67 & 0.37 & 2.67 & 0.27 & 2.33 & 0.23 \\
\hline $\mathrm{J}$ & 0.11 & 3.67 & 0.41 & 3.67 & 0.41 & 3.00 & 0.33 & 2.67 & 0.30 & 2.67 & 0.30 \\
\hline $\mathrm{K}$ & 0.09 & 3.33 & 0.29 & 3.67 & 0.32 & 2.67 & 0.23 & 3.00 & 0.26 & 2.67 & 0.23 \\
\hline \multicolumn{12}{|c|}{ Peluang } \\
\hline A & 0.13 & 3.00 & 0.38 & 3.67 & 0.46 & 3.33 & 0.42 & 4.00 & 0.50 & 2.67 & 0.33 \\
\hline B & 0.13 & 3.33 & 0.42 & 3.67 & 0.46 & 3.67 & 0.46 & 3.33 & 0.42 & 2.33 & 0.29 \\
\hline $\mathrm{C}$ & 0.09 & 3.67 & 0.34 & 3.33 & 0.31 & 3.33 & 0.31 & 2.67 & 0.25 & 2.33 & 0.22 \\
\hline $\mathrm{D}$ & 0.10 & 4.00 & 0.42 & 4.00 & 0.42 & 3.33 & 0.35 & 3.00 & 0.31 & 2.67 & 0.28 \\
\hline $\mathrm{E}$ & 0.14 & 3.67 & 0.51 & 4.00 & 0.56 & 3.00 & 0.42 & 3.33 & 0.47 & 2.67 & 0.37 \\
\hline \multicolumn{12}{|c|}{ Ancaman } \\
\hline $\mathrm{F}$ & 0.15 & 3.00 & 0.45 & 3.67 & 0.55 & 3.67 & 0.55 & 3.67 & 0.55 & 3.67 & 0.55 \\
\hline G & 0.14 & 3.33 & 0.47 & 3.67 & 0.51 & 3.33 & 0.47 & 2.33 & 0.33 & 2.00 & 0.28 \\
\hline $\mathrm{H}$ & 0.13 & 2.33 & 0.29 & 3.67 & 0.46 & 2.67 & 0.33 & 3.67 & 0.46 & 3.67 & 0.46 \\
\hline \multicolumn{3}{|c|}{ STAS } & 6.75 & & 7.25 & & 6.58 & & 6.09 & & 5.25 \\
\hline \multicolumn{3}{|c|}{ Peringkat } & 2 & & 1 & & 3 & & 4 & & 5 \\
\hline
\end{tabular}

Keterangan :

S1 : Strategi peningkatan kualitas aparatur pengelola BMD

S2 : Strategi peningkatan faktor pendukung kinerja aparatur pengelola BMD

S3 : Strategi penguatan kebijakan daerah tentang penempatan aparatur pengelola BMD

S4 : Strategi penguatan evektifitas penerapan perda tentang Fasos dan Fasum

S5 : Strategi pendekatan kepada masyarakat 
Berdasarkan Tabel 6 dapat dilihat urutan strategi prioritas untuk peningkatan implementasi penatausahaan aset tetap di Kota Bogor adalah sebagai berikut:

1. Strategi peningkatan faktor pendukung kinerja aparatur pengelola BMD

2. Strategi peningkatan kualitas aparatur pengelola BMD

3. Strategi penguatan kebijakan daerah tentang penempatan aparatur pengelola BMD

4. Strategi penguatan evektifitas penerapan perda tentang fasos dan fasum

5. Strategi pendekatan kepada masyarakat

Strategi prioritas pertama dan strategi prioritas kedua merupakan kombinasi strategi $\mathrm{S}-\mathrm{O}$ pada matrik SWOT. Jika dilihat dari kombinasi nilai IFE dan EFE strategi kombinasi S-O merupakan kombinasi dengan nilai IFE dan EFE tertinggi pada mastrik SWOT. Strategi ini juga menggambarkan strategi intensif dan integratif yang sesuai dengan strategi yang cocok untuk kuadran tumbuh dan membangun pada matrik IE. Strategi prioritas pertama mencerminkan strategi yang integratif, yaitu melibatkan berbagai pihak yang mendukung peningkatan kinerja. Strategi prioritas ke dua menggambarkan strategi intensif, yaitu keseriusan aparatur dalam upaya meningkatkan implementasi penatausahaan aset tetap di Kota Bogor.

Dengan peningkatan kualitas aparatur serta didukung oleh perbaikanperbaikan faktor yang mendukung peningkatan kinerja aparatur pengelola BMD akan mengurangi kelemahan dalam penatausahaan aset tetap yang dimiliki Pemerintah Kota Bogor. Oleh sebab itu dua strategi prioritas ini merupakan strategi yang direkomendasikan untuk dilakukan Pemerintah Kota Bogor.

\section{PROGRAM DAN IMPLIKASI KEBIJAKAN}

Agar strategi prioritas yang diperoleh dari hasil QSPM dapat memberikan manfaat untuk penatausahaan aset tetap di Kota Bogor maka strategi prioritas yang telah dihasilkan dari tersebut perlu dilaksanakan, sehingga perlu dilakukan penyusunan rumusan strategi dalam bentuk program dan kegiatan yang lebih rinci. Rumusan strategi tersebut merupakan acuan untuk memberikan arahan pada program dan kegiatan yang akan dilakukan dengan sumberdaya yang ada. Perancangan program tersebut disajikan dalam Tabel 7.

Tabel 7. Rancangan kebijakan peningkatan implementasi penatausahaan aset tetap

\begin{tabular}{|c|c|c|c|c|}
\hline Strategi & Kebijakan & Program & & Kegiatan \\
\hline \multirow{6}{*}{$\begin{array}{l}\text { Strategi } \\
\text { peningkatan faktor } \\
\text { pendukung kinerja } \\
\text { aparatur pengelola } \\
\text { BMD }\end{array}$} & \multirow{6}{*}{$\begin{array}{l}\text { Perbaikan } \\
\text { Pelaporan, } \\
\text { inventarisasi, } \\
\text { pemeliharaan, dan } \\
\text { pengamanan aset } \\
\text { tetap }\end{array}$} & \multirow[t]{2}{*}{$\begin{array}{l}\text { Penataan } \\
\text { Penguatan } \\
\text { Organisasi }\end{array}$} & 1 & $\begin{array}{l}\text { Menetapkan syarat jabatan untuk } \\
\text { aparatur pengurus barang dan } \\
\text { penyimpan barang }\end{array}$ \\
\hline & & & 2 & $\begin{array}{l}\text { Menyusun SOP penatausahaan } \\
\text { aset daerah }\end{array}$ \\
\hline & & \multirow{4}{*}{$\begin{array}{l}\text { Peningkatan } \\
\text { Pengelolaan } \\
\text { Daerah }\end{array}$} & 1 & Menerapkan sistem informasi \\
\hline & & & & $\begin{array}{l}\text { Barang Milik Daerah (Simda- } \\
\text { BMD) }\end{array}$ \\
\hline & & & 2 & $\begin{array}{l}\text { Melakukan penilaian kembali } \\
\text { terhadap aset tetap }\end{array}$ \\
\hline & & & 3 & Melakukan penghapusan aset tetap \\
\hline \multirow{4}{*}{$\begin{array}{l}\text { Strategi } \\
\text { peningkatan } \\
\text { kualitas aparatur } \\
\text { pengelola BMD }\end{array}$} & Pembinaan dan & \multirow{4}{*}{$\begin{array}{l}\text { Peningkatan } \\
\text { Kapasitas Sumber } \\
\text { Daya Aparatur }\end{array}$} & 1 & Diklat penatausahaan aset \\
\hline & Pengembangan & & 2 & Diklat penilaian aset daerah \\
\hline & Aparatur; & & & \\
\hline & & & 3 & Bimtek dan Sosialisasi \\
\hline
\end{tabular}


Berdasarkan dua strategi utama yang telah dirumuskan, terdapat tiga program (Tabel 7) yang harus dilakukan untuk meningkatkan implementasi penatausahaan aset tetap pada Pemerintah Kota Bogor. Program tersebut disesuaikan dengan program yang ada pada RPJMD Kota Bogor tahun 2014-2019. Rancangan kegiatan merupakan kegiatan yang belum terdapat pada RPJMD. Rancangan program dan kegiatan tersebut adalah:

1. Penataan dan penguatan organisasi

Penataan dan penguatan organisasi dilakukan untuk memberikan kenyamanan kepada aparatur agar aparatur dapat bekerja dengan baik, sehingga strategi peningkatan kinerja aparatur dapat tercapai. Program tersebut dijabarkan dalam kegiatan menetapkan syarat jabatan untuk aparatur pengurus barang dan penyimpan barang dan menyusun SOP penatausaan aset daerah.

2. Peningkatan pengelolaan aset daerah Peningkatan pengelolaan aset daerah dilakukan agar data pada penatausahaan aset tetap tersedia dengan baik dan lengkap. Kegiatan pada program ini adalah menerapkan sistem informasi Barang Milik Daerah (SIMDA-BMD), melakukan penilaian kembali terhadap aset tetap, dan melakukan penghapusan aset tetap.

3. Peningkatan kapasitas sumberdaya aparatur

Kegiatan pada program ini meliputi diklat penatausahaan aset tetap, diklat penilaian aset Daerah, bimtek dan sosialisasi.

\section{SIMPULAN DAN SARAN}

\section{Simpulan}

1. Kesempatan bagi aparatur untuk pengembangan SDM merupakan faktor internal yang menjadi kekuatan utama pada Pemerintah Kota Bogor, sedangkan faktor kelemahan utama adalah pengurus barang dan penyimpan barang masih mengerjakan pekerjaan selain tugas pokok dan fungsinya sebagai pengelola BMD. Faktor eksternal sebagai peluang utama adalah aturan ditingkat pemerintah pusat yang mendukung penatausahaan aset tetap dan dilakukannya evaluasi rutin yang dilakukan BPK, sedangkan faktor eksternal sebagai ancaman adalah tidak tertibnya pengembang dalam penyerahan fasos dan fasum yang menjadi kewajibannya.

2. Strategi prioritas yang dapat dilakukan Pemerintah Kota Bogor untuk peningkatan implementasi penatausahaan aset tetap pada Pemerintah Kota Bogor adalah strategi peningkatan faktor pendukung kinerja aparatur pengelola BMD dan strategi peningkatan kualitas aparatur pengelola BMD. Strategi peningkatan faktor pendukung kinerja aparatur pengelola BMD dapat mengakomodir strategi penguatan kebijakan daerah tentang penempatan aparatur pengelola BMD yang merupakan strategi keluaran dari kelemahan utama dan peluang eksternal yang dimiliki Pemerintah Kota Bogor melalui program penataan dan penguatan organisasi.

\section{Saran}

Pemerintah Kota Bogor perlu meningkatkan faktor pendukung kinerja aparatur seperti komitmen pimpinan untuk menggunakan sistem informasi manajemen barang milik daerah (SIMDABMD) dan penempatan aparatur yang sesuai dengan kompetensinya.

\section{DAFTAR PUSTAKA}

Anthoni, Richard. 2015. Strategi Penguatan Sistem Pengendalian Intern Dalam Penatausahaan Barang Milik Daerah Pada Pemerintah Kabupaten Bogor. Tesis. Bogor (ID): Institut Pertanian Bogor

Arlini M, Darwanis, Abdullah S. 2014. Pengaruh Kompetensi Sumber Daya Manusia, Sistem Informasi, Regulasi, dan Kompensasi Terhadap Manajemen Aset (Studi Pada Satuan Kerja Badan Kependudukan dan Keluarga Berencana Nasional di Indonesia). 


Jurnal Magister Akuntansi

Pascasarjana Universitas Syiah Kuala. Volume 3:4.

Assey TB, Kalegele K, Chanhage B. 2014. Faktors Influencing Fixed Aset Losses in Local Government Authorities in Tanzania. Academicjournals. 11(4): 69-73. DOI:10.5897/AJBM2016.8210

Azhar I, Darwanis, Abdullah S. 2013. Pengaruh Kualitas Aparatur Daerah, Regulasi, dan Sistem Informasi Terhadap Manajemen Aset (Studi pada SKPD Pemerintah Kota Banda Aceh). Jurnal Akuntansi Pascasarjana Universitas Syiah Kuala. Vol 2:1.

Batara AM, Rakhmat, Sadik MN, dan Ahmad B. 2015. Management Of Assets In New Public Management Perspective (Case Study: Optimization Of Lands And Buildings Asset At Local Government Of Makassar City). Quest Journals Journal of Research in Humanities and Social Science. Volume 3- Issue 8 (2015) pp:32-41 ISSN(Online) : 2321-9467

David FR, David FR. 2016. Manajemen Strategik Suatu Pendekatan Keunggulan Bersaing. Puspasari N dan
Puspitasari LN, Penerjemah; Halim DA, editor. Jakarta: Salemba Empat. Terjemahan dari: A Competitive Advantage Approach, Consepts, and Cases, 15th ed.

Kolinug MS, Ilat V, Pinatik S. 2015. Analisis Pengelolaan Aset Tetap Pada Dinas Pendapatan Pengelolaan Keuangan Dan Aset Daerah Kota Tomohon.Jurnal EMBA. Vol (3) No.1; 818-830.

Lu Yaotai, 2011, Public asset management: empirical evidence from the state governments in the united states, Dissertation to the Faculty of The College for Design and Social Inquiry in Partial Fulfillment of the Requirements for the Degree of Doctor of Philosophy.

Nordiawan D, Putra I.S, Rahmawati M. 2008. Akuntansi Pemerintah. Jakarta (ID): Salemba Empat

Sihombing NS. 2016. Strategi Peningkatan Kinerja Aparatur Pengelola Aset Daerah Di Kabupaten Tapanuli Tengah. Tesis. Bogor (ID): Institut Pertanian Bogor 